\title{
HONRA MODERNA E POLÍTICA EM MAX WEBER*
}

Carla Costa Teixeira

O horizonte empírico ao qual se refere a obra de $\mathrm{M}$ ax Weber, e no qual desenvolve suas indagações teórico-metodológicas, favoreceu de modo particular diferentes reapropriações de seu pensamento. Nesse sentido, os trabalhos de Weber ofereceram, neste século, contribuições inestimáveis a diversas especializações sociológicas, além de constituírem uma inspiração permanente para reflexões teóricas com diferentes orientações de reconhecida relevância ${ }^{2}$. Daí que nós, leitores dos estudos de Weber, dispomos de uma gama considerável de intérpretes e mediadores. Se, por um lado, isto se configura como um elemento revitalizador da própria obra de Weber, por outro, requer do leitor-investigador cuidado e perspicácia na exploração desse autor, principalmente quando se trata de alguém oriundo de uma tradição das ciências sociais que - como a antropologia - não se constituiu elegendo Weber como um de seus fundadores. Ciente dessa inserção, procuro explorar a compreensão weberiana da política sob a inspiração permanente, embora nem sempre explícita, do material etnográfico proveniente de pesquisas por mim realizadas no Congresso Nacional. Desta perspectiva, vou ao encontro do espírito weberiano que vislumbrou nos estudos da cultura um potencial peculiar à investigação das existências humanas: sua intrínseca parcialidade e conceituação contextualizada. Assim, expressando-me em termos weberianos, o que apresento é uma reflexão acerca de alguns ângulos do significado da ação política iluminada pelos desafios de nossa "individualidade histórica".

A s investigações no Congresso $\mathrm{N}$ acional consistem em um estudo sobre as concepções de decoro parlamentar no universo político brasileiro, em especial no contexto da Câmara dos Deputados, onde analisei diferentes casos legislativos de perda de mandato entre 1949 e 19942. O decoro parlamentar é uma figura jurídica presente na Constituição brasileira e nos regimentos internos da Câmara e do Senado, que permite penali- 
zar os parlamentares que a infringirem, em uma gradação de punições que vai desde a advertência verbal até a perda do mandato. A atualização do dispositivo constitucional do decoro em sua singularidade concreta, ou seja, a observação do decoro parlamentar em ação, revelou-o particularmente útil para pensar relações e valores essenciais do mundo político brasileiro. E o mais importante aqui : trouxe à reflexão teórica critérios de rel evância empírica que permitiram recolocar a discussão weberiana da vocação dos políticos e da política tendo a honra como seu valor distintivo, em detrimento de sua definição mediante padrões de interesse de classe ou status. A conceituação e o julgamento por quebra de decoro parlamentar não se limitam a tipificar atos impróprios ao exercício do mandato, mas prescrevem uma avaliação do comportamento do parlamentar segundo critérios de "dignidade" e "honra" definidos por seus pares; não normatizam o desempenho de um papel social específico (o de representante político), mas pretendem abarcar a totalidade da conduta do sujeito em questão, esteja ele ou não no exercício de suas funções políticas. Desse modo, a honra, enquanto hierarquia de valores particularistas e contextualizados, é apresentada nos casos de quebra de decoro como o critério central acionado no juízo de valor da conduta política: é o discurso que articula e legitima a precedência e a singularidade do pertencimento político sobre as demais inserções sociais.

Caberia aqui destacar uma reflexão de Wolfgang Schluchter em Paradoxes of Modernity, que adquiriu relevância singular no diálogo entre teoria e dados etnográficos, cujas linhas gerais traço neste artigo:

"The conceptual distinction in connection with politics is not useful versus harmful, nor is it true versus false or beautiful versus ugly, nor is it even good versus evil; it is honorable versus disgraceful. Failure to satisfy a political duty does not provoke feelings of discontent or guilt as much as it does those of shame" (Schluchter 1996:13-14).

Tal afirmação tem, de imediato, a força de provocar certo estranhamento no senso comum em relação às ações sociais em geral em um mundo moderno que se acredita racional. Mas o faz, também, em certas tradições das ciências sociais que circunscrevem valores como honra e vergonha aos estudos de sociedades tradicionais e que, quando os evocam em contextos modernos, o interpretam a priori como indicadores de dimensões hierárquicas negativas existentes nessas sociedades. Quero enfatizar, contudo, que, com relação especificamente à política moderna, o destaque para honra e vergonha mostrou-se fonte de inspiração para 
esclarecer vários dados etnográficos recolhidos na época, bem como desencadeou o processo inverso que fez com que os dados etnográficos iluminassem a idéia contida na citação. Se a importância da honra na perspectiva weberiana da política, "descoberta” em Schluchter, se revelou central para a compreensão dos fatos que a pesquisa descrevia, ao mesmo tempo os elementos trazidos pela etnografia possibilitaram esse exercício de aprofundar, nos próprios textos de Weber, o entendimento dessa relevância tão sumariamente anunciada. É este plano que será fonte das reflexões aqui desenvolvidas.

\section{Éticas (no plural)}

Weber, ao delimitar as fronteiras da esfera política, toma como contraponto cinco outros domínios: ciência, religião, burocracia, economia e ética (Weber 1974; 1995). É no diálogo com as virtudes de cada um destes que a especificidade da política vai se delineando. Aqui, devido à inserção etnográfica, enfatizarei a comparação entre política e ética. As demais esferas, portanto, far-se-ão presentes na medida em que contribuírem para a sua compreensão.

Os valores políticos, diz Weber, não podem ser reduzidos a valores éticos; o universo da política não se confunde com o da ética. Em um mundo concebido como uma totalidade hierarquizada, cada dimensão tem uma ética particular que se integra ao todo, segundo uma cosmologia que atribui preceitos distintos a inserções distintas (como ocorre, por exemplo, na ordem de castas indiana e na doutrina de salvação cristã). Mas a ética no mundo moderno constitui-se a partir de valores universalistas e igualitários, toma como referência o indivíduo e faz exigências absolutas à sua consciência. Assim, a fragmentação das esferas de valor engendrou um aparente paradoxo: a ética tornou-se um domínio relativamente autônomo, dotado de lógica própria; porém, simultaneamente, a ética teve de se especializar, pois cada esfera da vida, também, por sua vez, segue leis particulares. Nas palavras do próprio Weber, refletindo sobre a univocidade da ética moderna:

“Como se coloca, então, o problema das verdadeiras relações entre a ética e a política? Será certo, como já se afirmou, que não há qualquer relação entre essas duas esferas? Ou seria mais acertado, afirmar, pelo contrário, que a mesma ética é válida para ação política e para qualquer outro gênero de ação? J á se acreditou que exista oposição absoluta entre as duas teses: seria 
exata uma ou a outra. Cabe, entretanto, indagar se existe uma ética que possa impor, no que se refere ao conteúdo, obrigações idênticas aplicáveis às relações sexuais, comerciais, privadas e públicas, às relações de um homem com sua esposa, sua quitandeira, seu filho, seu concorrente, seu amigo e seu inimigo. Pode-se, realmente, acreditar que as exigências éticas permanecem indiferentes ao fato de que toda política utiliza como instrumento específico a força, por trás da qual se perfila a violência?" (Weber 1998:111).

A qui Weber traz para o debate, de forma contundente, a natureza trágica da ação política e, desse modo, a tensão que marca as relações entre ética e política. Pois, se toda ação humana está sujeita à tragédia de ver o mal advir de intenções absolutamente corretas, ou seja, de inserir-se em um mundo eticamente irracional, a conduta política experimenta tal possibilidade de maneira excepcional. A política é o reino do poder e da força; estes são os instrumentos específicos de que dispõem os políticos, sendo o seu dilema ético quando e de que forma usá-los e através de que mecanismos legitimá-los.

As respostas a este dilema, porém, não podem ser buscadas na consciência individual, pois as convicções íntimas não chegam a se constituir em critério suficiente na política. Há que se considerar as prováveis conseqüências de uma determinada conduta política, ou seja, o contexto e a inserção dos diferentes sujeitos políticos e do sujeito da ação nesse contexto. Caso contrário, provoca Weber, estaríamos diante de uma pessoa ingênua, alguém que ignora que na política se faz um "pacto com as potências diabólicas" (Weber 1998:116).

A natureza demoníaca da política, em linhas gerais, deve ser entendida na conexão entre, por um lado, a natureza de seus meios (poder, força, violência) e o potencial de destruição e descontrole da ação humana que evoca, e, por outro, o estatuto especial do dever político3, que restringe as pretensões universalizantes da ética, exigindo sua particularização ao rejeitar imperativos incondicionais. Ao contrário do que ocorre na esfera da ética, o dever político tem como referência o indivíduo enquanto membro de uma coletividade historicamente definida, e não o indivíduo como um valor em si. O político (profissional ou ocasional) é um indivíduo que vive e se move em configurações socioculturais específicas, em um duplo sentido: por um lado, o que ele está disposto e inclinado a reconhecer como um princípio de validade geral depende de suas próprias convicções íntimas e, estas, ele adquiriu como participante em um determinado mundo; por outro, sua condição de pertencimento levao a ter de responder por suas ações em face e a partir do grupo social e 
cultural em que se insere. A política constitui-se, assim, sobre valores particularistas, mas, ao mesmo tempo, não pode abdicar de preceitos éti$\cos$, na medida em que engendra deveres e virtudes que, se específicos a essa esfera, nela se pretendem valores universalizáveis.

De qualquer modo, as duas esferas (a da política e a da ética) não se sobrepõem. As exigências que a política impõe a quem nela se insere são fortemente marcadas por "indicações de conteúdo" para avaliação da ação (Weber 1995), fazem parte do reino dos "valores culturais" e não podem encontrar soluções absolutas e obrigatórias em premissas éticas. Por outro lado, os imperativos éticos quando atualizados na ação política geram impasses que não podem ser resolvidos nos limites da própria ética - um bom exemplo pode ser verificado na investigação dos limites e possibilidades dos chamados "direitos humanos" 4 . A final: "No que diz respeito aos valores, na realidade, sempre e em toda parte, definitivamente, não se trata de alternativas, mas de uma luta de vida e morte irreconciliável entre ‘Deus' e o ‘Demônio'” (Weber 1995:374).

$\mathrm{Na}$ vida cotidiana, porém, em especial no âmbito das avaliações prático-políticas, valores opostos entrecruzam-se e se superpõem. Aqui não se trata de buscar um sistema de valores logicamente coerente (embora tal busca possa até existir) ou de pretender alcançar um meio termo entre valores que são em si inconciliáveis, mas, sim, de tomar posição em situações concretas, muitas vezes sem ter consciência de conflitos de valores - e às vezes exatamente por isso.

Estamos aqui no cerne da vocação (da) política: o delicado equilíbrio entre convicção e sucesso requerido pelas relações de poder que a singularizam vis-à-vis as demais esferas. $\mathrm{N}$ isto consiste a ética da responsabilidade postulada por Weber. Aqui, o sujeito político está envolvido em dois tipos de responsabilidades: ele deve responder pelo valor ético (de convicção) e pelo valor de eficiência (de sucesso) de sua ação. O político responsável, portanto, não opta exclusivamente por nenhum destes valores, ao contrário do que ocorre com o político de princípios e o político de resultados (Realpolitik), pois o político responsável é aquele capaz de vivenciar seus princípios últimos como possibilidades reais.

O político de convicção em sua plenitude é aquele que rejeita (1) o valor ético do sucesso - interface da política com a esfera econômica; e (2) o valor ético do conhecimento (razão e tecnologia) - interface da política com a esfera da ciência. Por um lado, permite tornar secundária a avaliação dos desdobramentos indesejáveis da decisão a ser tomada e, por outro, exime-se da responsabilidade por sua causação. Para ele, a ação, pelo fato mesmo de ter sido realizada, adquire valor como atualiza- 
ção da convicção que a gerou (é o "marcar posição" do vocabulário político corrente); a própria ação torna-se um fim em si, não consistindo em um meio para atingir objetivos outros. O político de convicção é, portanto, um adepto da ética de fins últimos e somente julga ter obrigações diante do tribunal da sua consciência. A causa final de sua conduta pertence a outro mundo e, nesse sentido, para Weber, o político de convicção - seja ele um militante revolucionário ou um militante religioso negaria a existência mesma de uma ética propriamente política, ignorando a especificidade ética da ação política advinda de seus instrumentos singulares (força e violência) em suas inevitáveis conseqüências (Weber 1998:118-120).

Já o político que maximiza a idéia da eficiência na definição da boa ação atua segundo a lógica da "política do poder" (Weber 1998:108), ou seja, o culto do poder em si. Trata-se do político de resultados que, pela ausência de princípios norteadores, não logra atingir outro objetivo que não a própria perpetuação no poder - ou seja, alguém que é incapaz de defender uma causa, de se dedicar "ao deus ou ao demônio que a inspira" (Weber 1998:106) e, portanto, de engendrar significado positivo à sua existência.

Com essas reflexões, Weber conclui ser a demanda específica da política justamente o desenvolvimento da capacidade de ponderar, de manter um certo equilíbrio entre paixão e perspectiva, entre o desejável e o possível. O verdadeiro político de vocação seria, portanto, o político responsável. Aquele político capaz de sacrificar al gumas de suas convicções, se assim o contexto exigir, mas que em determinado momento, no limite de seus princípios, pode vir a dizer: "Não posso fazer de outro modo; detenho-me aqui" (Weber 1998:122). Na verdade, na ação política não estão em jogo apenas o poder ou a paz e a satisfação individuais embora estes existam - mas, sim, esforços responsáveis por uma causa que, apesar de transcendente ao indivíduo, requer convicções pessoais. A política não é em si o reino das intenções e da força, a política é por excelência o mundo das realizações comprometidas em contexto.

Aqui chegamos ao significado fundamental da postulação da honra como critério distintivo da política. Para Weber, a especificidade do dever político está no exercício ponderado da responsabilidade, entendida como capacidade de agir e de responder pela retidão e eficiência da conduta em situações concretas. Seria, portanto, inerente à própria construção do sujeito político comprometer-se, no duplo sentido que esta ação comporta: assumir compromisso e comprometer outrem. A condição de pertencer mostra-se, assim, intrínseca à vida política. E neste pertenci- 
mento necessário residiria a possibilidade de constituição de uma honra que não se confunde com a noção moderna de dignidade. Se a dignidade moderna remete à existência de uma qualidade humana essencial (Humanidade, com maiúscula), a honra encontra o significado da realidade humana em sua singularidade e individualidade histórica (humanidades, no plural). E, para Weber, o caráter diferenciado e localizado dos sujeitos em ação (que a dinâmica da honra pressupõe e recria) é essencial à especificidade da própria esfera política.

\section{Honra e vocações}

A noção de honra não foi objeto específico de reflexão para Weber. É preciso realinhar idéias que se encontram dispersas ao longo de vários de seus textos, pois se o autor nos oferece indícios, a responsabilidade de elaborar conclusões é do leitor. A honra não era a sua temática central nos trabalhos sobre sociedades modernas. $M$ as, ao tratar da vocação política, Weber abre-nos a possibilidade de pensar uma honra moderna, ultrapassando os limites das sociedades estamentais. Assim, a noção de honra, em Weber, pode ser articulada em dois planos de análise: ancorase em realidades históricas, mas, ao mesmo tempo, estrutura-se como um conceito-tipo. Se a "honra" não pode ser compreendida com a pretensão de universalidade de seus conceitos sociológicos fundamentais, tampouco deve ser restringida a uma única realidade histórica. Honra seria, utilizando a classificação de Gunther Roth (Roth e Schluchter 1979), um conceito sociohistórico, uma generalização de abrangência empírica relativa.

Em “Política como Vocação", Weber menciona vários tipos de políticos profissionais em suas relações com a honra. Ao analisar a organização do domínio permanente, fala em "honra do servidor público", referindo-se ao princípio de integridade sem o qual "estaríamos ameaçados por uma corrupção assustadora e não escaparíamos ao domínio dos filisteus" (Weber 1998:69). Já na apresentação dos principais tipos de políticos profissionais, refere-se ao "jornalista honrado": aquele que possui senso de responsabilidade, que tem consciência dos efeitos que as realizações jornalísticas podem provocar (Weber 1998:80). Quando trata do chefe político norte-americano (o boss), afirma que este não "está à procura de honrarias sociais; o profissional (assim o denominam) é, sem dúvida, desprezado pela 'alta sociedade'. Ele só busca o poder, seja como fonte de riquezas, seja pelo próprio poder" (Weber 1998:98) - não tem, portanto, doutrina definida ou princípios políticos. Finalmente, nas indaga- 
ções diretas sobre as relações entre ética e política, Weber dialoga com o contexto da Europa pós-Primeira Guerra M undial, comentando a questão da honra alemã nos seguintes termos:

“Uma nação sempre perdoa os prejuízos materiais que Ihes são impostos, mas não perdoa uma afronta à sua honra, sobretudo quando se age à maneira de um predicador, que pretende ter razão a qualquer preço. Documentos novos trazidos a conhecimento público dezenas de anos após o término de um conflito só podem trazer como resultado despertar clamores injustificados, cólera e ódio, quando seria melhor esquecer a guerra, moralmente ao menos, depois de ela terminada. Tal atitude só é possível, entretanto, quando se tem senso da realidade, o senso do cavalheirismo e, acima de tudo, o senso da dignidade. E essa atitude impede que se adote uma 'ética' que, em verdade, sempre é testemunho de uma falta de dignidade de ambos os lados. Esta última espécie de ética só se preocupa com a culpabilidade no passado, questão estéril do ponto de vista político, porque insolúvel, e não chega a preocupar-se com o que se constitui no interesse próprio do homem político, ou seja, o futuro e a responsabilidade diante do futuro" (Weber 1998:110).

Esta passagem revela que honra e dignidade, para Weber, não são excludentes, mas combinam-se na construção do que chamarei honra moderna. Honra e dignidade seriam expressões distintas de um mesmo fenômeno denominado em determinados momentos pelo autor com a expressão estima social (cf. Weber 1974, Parte II, caps. VI e VII). Dessa perspectiva, a honra estamental consistiria em um tipo de honra específica, aquela cujos fundamentos são a distância e o sentimento de exclusividade e de distinção posicional atribuídos a priori. No caso das democracias modernas, onde a igualdade de estima social é um valor (Weber 1974:219), tais honrarias seriam vistas, na verdade, como vergonha, pois a honra consistiria na estima social a ser conquistada por aqueles que lograssem encarnar o estilo de vida adequado ao seu mundo.

A honra, portanto, não tem um conteúdo substantivo em Weber daí não constar na enumeração feita pelo autor das três qualidades que são decisivas para o político: paixão, responsabilidade e senso de proporção (Weber 1998:106); tampouco constitui a princípio um mecanismo instaurador e perpetuador de privilégios. Trata-se, antes, de uma dinâmica atribuidora de valor social que se estrutura a partir do sistema de valores de cada sociedade e que sempre implica reconhecimento, portanto, algum tipo de pertencimento. Aquele que fosse anônimo e radicalmente desenraizado, estaria fora do alcance da dinâmica de honra e vergonha. 
M as a honra que se esgota no critério de sucesso externo não chega de fato a se configurar na verdadeira honra, assim como não é suficiente a paixão que se limita à exaltação de uma emoção íntima. Esta é o que Weber chamou, remetendo-se a Georg Simmel, de "excitação estéril"; aquela consiste em um gosto pela sensação de poder que a carreira política proporciona (Weber 1998:106). Em ambas faltariam os sentimentos de dignidade e de auto-estima: a precipitação nos indivíduos da honra social, ou seja, a convicção de pertencer a um todo singular e, exatamente por isso, ter o dever de se conduzir de determinada forma. A pretensão à honra seria, então, a expressão, no plano das interações sociais, de uma adesão íntima a um dado conjunto de valores. Por isso, a honra é sempre passível de dupla sanção: interna ("vergonha" e "culpa") e, principalmente, externa ("desonra" e perda de "prestígio social"). A honra, portanto, é uma dinâmica e um idioma de distinção social que, nas sociedades tradicionais, traduz a hierarquia existente em um idioma de privilégios e preferências. Contudo, nas sociedades modernas, a honra permite expressar a diversidade de valores subjacentes ao princípio hegemônico de igual dade porque, ao produzir uma hierarquia de valores, reintroduz a diferença em uma realidade que parecia fadada ao nivelamento, abrindo, assim, a possibilidade de negociações em contexto 5 .

No caso específico da honra nacional, Weber destaca que as relações entre as comunidades políticas são profundamente marcadas pela luta por prestígio, o que pode desencadear um tipo de conduta externa expansionista: o "imperialismo". A honra nacional, assim como a honra estamental, seria excludente, pois a glória de uma nação implica o domínio (incorporação ou sujeição) de outras. M as, mesmo no caso da nação, Weber aponta para a existência de uma honra moderna estruturada em termos de relações igualitárias, na qual haveria uma dinâmica de reconhecimento em que, a priori, todas as comunidades políticas poderiam ser contempladas - já que não se trataria de um valor que, como na honra estamental, para um sujeito ter, outro teria de perder. Esse ideal de honra moderna, colocado por Weber no debate sobre a nação, consiste em uma postura de solidariedade vis-à-vis outros grupos, que se expressa na idéia de "insubstituibilidade de valores culturais", ou seja, na afirmação de valores "que devem ser preservados e desenvolvidos exclusivamente através do cultivo da peculiaridade do grupo" (Weber 1974:206). É específico da honra moderna ter de conciliar os direitos universais do humanismo moderno ocidental (englobados na noção de dignidade) com o reconhecimento político do valor de culturas particulares 6 ("nação", "espírito"). 
A honra moderna, portanto, não se confunde com o culto à imagem ou prestígio. Honrado, no mundo "desencantado", é aquele que logra ser reconhecido por uma trajetória bem-sucedida na afirmação dos valores últimos que seu pertencimento Ihe legou. Nesse momento, Weber reafirma o estilo de vida ético adequado à modernidade - a ética da responsabilidade - e deixa-nos a reflexão sobre as razões pelas quais a ética da responsabilidade encontra sua expressão maior (sob a dinâmica da honra) na esfera política, daí emanando para as demais esferas de valor.

A política é um mundo de valores peculiar para Weber e não goza das isenções que as demais esferas usufruem - a "neutralidade" da ciência ou a obediência "irresponsável" da burocracia. O político não executa metas, o político toma as decisões; o político não analisa criticamente orientações de valor, o político produz juízos de valor; o político não discursa sobre a realidade, o político ao falar já atua sobre ela. Daí advém a conclusão de que, mais que em qualquer mundo de valor, na política é fundamental que o indivíduo abrace conscientemente a ética da responsabilidade como um valor. O cientista e o funcionário público podem desempenhar vários papéis, os quais eles buscam, conforme a situação, integrar. Mas toda vez que aderirem e lutarem por outros valores culturais que não os pressupostos que fundamentam a própria existência de suas respectivas esferas (a ciência e a burocracia), estarão, na interface com a política, atuando como sujeitos políticos. Isto pode gerar impasses insolúveis se tal distinção de valores não for compreendida. Enquanto esferas de val or separadas, política, ciência e burocracia fazem demandas distintas sobre os sujeitos que nelas se inserem, produzindo vocações específicas.

A burocracia, para Weber, encontra sua vocação no exercício consciencioso e honesto da função pública; portanto, a vocação especificamente política começa onde termina a da esfera burocrática. Se o burocrata deve el evar a regra e a ordem à condição de convicção pessoal, o político de vocação tem o dever de lutar para transformar suas convicções íntimas em ordem e regra. Assim, nos alerta Weber, confundir esses deveres vocacionais aviltaria duplamente a vida política: na organização do domínio permanente e no exercício da liderança política. Tal contraste expressa-se empiricamente no código de ética do servidor público no Brasil - com sua prioridade à distinção entre procedimento honesto e desonesto - e no regimento interno da Câmara dos Deputados, que submete o juízo sobre o procedimento do parlamentar à figura do decoro e à preservação da dignidade e honra do mandato. 
A ciência, por sua vez, é um meio importante em Weber para a atuação do político responsável, ao possibilitar uma certa racionalização da realidade mediante o conhecimento que produz. Essa participação instrumental seria, contudo, secundária em face da contribuição da ciência à dimensão valorativa da vida política; não da perspectiva de proferir juízos de valor, mas de promover as orientações de valor que devem guiar o político profissional: o auto-esclarecimento e o senso de responsabilidade, na medida em que a ciência, por sua própria vocação, trabal ha com a elaboração e a experimentação de diferentes pontos de vista. Dessa forma, pode cultivar distanciamento e clareza no sentido do que Weber chamou, em termos de vocação política, de "senso de proporção" (Weber 1998:106). Esses são os limites da ciência em sua interação com a política e, ao mesmo tempo, sua dimensão ética fundamental: contribuir para a formação da personalidade do político de vocação, sem nunca tomar para si suas realizações.

Mas, é importante destacar, "personalidade" não é atributo presente apenas no reino da política, é uma noção bem mais abrangente: é condição para o bom desempenho do dever vocacional em qualquer esfera. Personalidade, tampouco, é algo inato, embora exija certos dons; é constituída por uma certa experiência pessoal, fruto da ligação íntima entre consciência ("de sua posição e situação"), dedicação ("servir à sua obra, e apenas a ela") e competência ("inspiração"). Personalidade é uma categoria que traz o indivíduo para a análise sociológica no sentido de que, diferente da noção de Bildung (self-cultivation) tão cara à tradição germânica, a personalidade weberiana não tem como foco o desenvolvimento do self através da modelação e formação consciente do corpo, mente e espírito. $O$ desenvolvimento do self adquire significado enquanto instrumento central das realizações mundanas e seu valor depende da continuidade sistemática das ações do indivíduo, ou seja, do que ele faz e não do que ele é no mundo 7 . Ainda, a noção de personalidade permite, no plano teórico-metodológico, transitar entre as várias esferas de valor, desvendando as múltiplas facetas da tensão entre conviç̧ão e unidades de propósitos, necessária à transformação do sujeito em personalidade, e a inevitável pluralidade de valores de um mundo desencantado, muitas vezes apreendida como um caos de valores.

Sem dúvida, porém, personalidade é um valor para o próprio Weber, que a insere em um quadro do individualismo humanista e ascético (Schluchter 1996); remete à capacidade do indivíduo de fazer escolhas e empreender esforços responsáveis em prol de uma "causa", tomando como referência determinados valores fundamentais. Implica, portanto, 
auto-renúncia que somente a paixão autêntica por uma causa pode propiciar. M as requer, como visto, responsabilidade e distanciamento do próprio eu, dos outros e das "coisas". Essas são as qualidades necessárias ao político de vocação, mas sua especificidade vocacional reside no tipo de vínculo entre indivíduo e mundo dessacralizado que é, nessa esfera, capaz de constituir uma personalidade. Refiro-me, em especial, ao pertencimento atribuidor de honra, ou seja, à condição de membro atuante de uma comunidade política em cuja hierarquia de valores a "nação" surge como causa e paixão fundamentais - valor maior para Weber e suas preocupações com a Alemanha de sua época. Contudo, vale lembrar que Weber compreende a idéia de nação em sua ambigüidade e polissemia, definindo-a no campo da política como uma "comunidade de sentimento" com tendência a se organizar em um Estado próprio, mas que neste não se esgota e nem com este se confunde (Weber 1974:207). Desta perspectiva, pode-se compreender a ênfase dada por Weber à "honra" na citação transcrita acima, em que o autor discute a condição da nação alemã no pós-guerra, bem como o uso freqüente de expressões tais como "combate" e "Iuta" em seus escritos políticos, que indicam não apenas a especificidade dos meios políticos (poder e força) mas, também, linhas de continuidade com a dimensão viril da honra no contexto alemão que, historicamente, tem na corporação militar sua referência privilegiada 8 .

\section{A honra na política moderna}

A honra é um mecanismo social que implica reconhecimento e pertencimento, um pertencer que hierarquiza todas as demais inserções do sujeito. Assim, não há uma pluralidade de honras e tampouco há honra privada, uma vez que esta só encontra expressão no mundo público. A questão que permanece é: a honra é pública; mas por que dentro do mundo público é o critério distintivo da política? A resposta deve ser buscada na compreensão da singularidade histórica em que a honra logrou alcançar o lugar diferencial específico da esfera política, ou seja, na modernidade.

N esta, o mundo público realizaria ao extremo as relações à distância (racionais e não afetivas) que a vida anterior em comunidades locais praticamente desconhecia (Weber 1964) ${ }^{9}$. Agora, o desconhecido não mais se esgota no elemento estrangeiro, passa a fazer parte da própria comunidade mais abrangente: a nação. $\mathrm{N}$ as grandes cidades, como analisou 
Georg Simmel, o desconhecido torna-se próximo, vigorando, assim, um anonimato relativo ${ }^{10}$. Nesse sentido, o domínio público deixa de ser visto como o locus do reconhecimento, transformando-se no espaço de circulação de indivíduos iguais, indiferenciados e indiferentes, onde impera o racionalismo instrumental. Em Weber podemos encontrar tal formulação quando ele conclui que:

“O destino de nosso tempo, que se caracteriza pela racionalização, pela intelectualização e, sobretudo, pelo 'desencantamento do mundo', levou os homens a banirem da vida pública os valores supremos e mais sublimes. Tais valores encontraram refúgio na transcendência da vida mística ou na fraternidade das relações diretas e recíprocas entre indivíduos isolados" (Weber 1998:51).

A qui observamos que, buscando compreender a especificidade de seu tempo, Weber (mais do que criticar o espaço público) afirma a inadequação daqueles que operam na vida pública segundo a lógica das relações pessoais ou da vida religiosa. Sua preocupação é articular o valor positivo singular das relações suprapessoais no mundo "desencantado", em um mundo onde os próprios indivíduos são os principais sujeitos de seus destinos.

Dessa compreensão do mundo moderno advém a importância da ética da responsabilidade na sua teoria do valor. Responsabilidade que alcançaria maior relevo na esfera de valor, que se distingue justamente por se constituir no espaço decisório do, ou sobre o, grupo social: a esfera política. Daí resultaria também o fato de a vida pública nunca ser apenas, ou principalmente, constituída de seres anônimos, livres e portadores de iguais direitos e deveres. Se, no plano fenomenológico, as relações humanas podem ser vivenciadas dessa forma, devido à navegação individual cotidiana entre círculos sociais múltiplos, por outro lado, o espaço por excelência de construção de identidade do indivíduo, de sua constituição enquanto sujeito, é a vida pública. E o político, na figura do líder, é a realização maior desse encontro entre indivíduo e sociedade, aquele que conseguiu fazer com que o grupo se reconhecesse nele próprio. Estamos próximos à noção weberiana de carisma. Embora esta não seja objeto de análise privilegiada neste texto, é importante notar que a ética da responsabilidade não exclui o carisma. Para Weber, o líder carismático é a expressão mais elevada da vocação política (Weber 1998:58); o que a ética da responsabilidade faz é adequar a realização do carisma às condições do mundo moderno. Daí que o fim do reconhecimento do líder 
político acione um tipo de sanção que conjuga controle externo mediante a recusa da própria condição de pertencimento social (desaprovação, punição material e exclusão social) - e, subjetivamente, a perda do próprio auto-respeito, ou seja: (des)honra e vergonha.

A natureza da política pode agora ser traduzida na tensão que lhe é constitutiva: mobilizar e reafirmar vínculos sociais em uma esfera que, ao autonomizar-se, o fez sob a égide do igualitarismo homogeneizador. Utilizando uma linguagem mais familiar ao debate empreendido por antropólogos, "indivíduo" e "pessoa" não seriam mais a priori universos de valores distintos. Podem, segundo a leitura que proponho dos textos de Weber, ser pensados como elementos intrínsecos à própria razão de ser da política na vida pública, pois o político, da perspectiva weberiana aqui apresentada, é, por excelência, um indivíduo imerso em sua condição de membro de uma coletividade historicamente definida. Um tipo de pertencimento que articula responsabilidade individual qualificada à identificação entre indivíduo e grupo social, produzindo a diversidade de políticos profissionais. Em uma era marcada pela pluralidade de valores, essa condição de pertencer pode maximizar o caráter conflituoso da política, fazendo com que os próprios valores que fundaram a política moderna se vejam questionados em seu domínio. M as como o pertencimento do sujeito político é essencial para a distinção e a autonomia da própria esfera política ante as demais esferas de valor, o paradoxo deve ser resolvido por uma reelaboração dessa própria condição.

\section{Honra e decoro parlamentar}

Foi dessa perspectiva que o decoro parlamentar revelou-se um instituto original da política brasileira ao institucionalizar a honra como critério distintivo da política, pois regimentalmente o parlamentar que "descumprir os deveres inerentes a seu mandato, ou praticar ato que afete a sua dignidade" (Regimento Interno da Câmara dos Deputado, 1994:155, Art. 244), está sujeito a um processo por quebra de decoro parlamentar. Assim, a noção de decoro englobou, através da idéia de dignidade, a vida pública e a vida privada sob o domínio da existência política; regulamentouas, ignorou a segmentação de papéis sociais, integrando-os à política e, desse modo, o decoro afirmou a autonomia da política em face do ambiente normativo abrangente. Observamos os acusados nos processos de cassação de mandato parlamentar na Câmara dos Deputados utilizarem, sem sucesso, argumentos jurídicos a fim de desautorizar o julgamento enquan- 
to injusto, pois político. Por tal procedimento, tornavam explícito o receio de perder o mandato em um tipo de julgamento onde critérios políticos minimizam os critérios jurídicos, em uma combinação na qual os valores da honra e da dignidade permitem ao conjunto de pares avaliar em cada situação qual a conduta que deve ser considerada incompatível com o decoro, independente de esta se configurar juridicamente em crime ou não. O que está em questão nesse embate é a eficácia da instituição do decoro para punir de forma ágil aqueles cujo procedimento (e não atos isolados) seja considerado uma desonra à condição de membro do Legislativo, ou ainda, à própria independência da esfera política (Teixeira 1998).

A questão, contudo, que as investigações etnográficas vêm revelando é que o englobamento da esfera política sobre as demais nem sempre tem sido feito em termos dos valores que a singularizam. $M$ ais do que uma figura jurídica, decoro é uma categoria social que se pauta pela interação da esfera privada com a esfera pública, e que, no caso específico brasileiro, assume por vezes uma relativa continuidade com práticas políticas sancionadas negativamente pela democracia representativa moderna (nepotismo, clientelismo, personalismo etc.). Refiro-me a um dado sistema de valores em que o bom exercício da função política tem sido reduzido ao não recebimento de vantagens materiais ilícitas, devido não a fatores fortuitos e passageiros, mas a uma construção social do mundo político que tem como referência principal (re)produzir uma certa separação entre público e privado.

Assim, tivemos no "escândalo do orçamento" um deputado federal, Ibsen Pinheiro (PM DB/RS), cassado por "enriquecimento ilícito" - apesar de não ter havido comprovação das conexões entre seu enriquecimento e o chamado esquema do orçamento; e outro deputado, Ricardo Fiúza (PFL/PE), absolvido porque não se provou a obtenção de ganhos materiais pessoais - apesar das graves acusações de que Fiúza teria acrescentado emendas ao orçamento após sua votação em plenário do Congresso Nacional. $\mathrm{O}$ instituto do decoro parlamentar revelou-se na comparação minuciosa destes dois processos, apenas pontualmente trazida neste artigo, de grande eficácia na punição de personalidades políticas, mas não na erradicação de procedimentos institucionais considerados danosos à dinâmica democrática (Teixeira 1998). Assim, de tempos em tempos, ressurgem denúncias acerca de irregularidades na elaboração orçamentária no Congresso, tendo gerado inclusive outro processo de cassação de mandato, no caso, contra o deputado Pedrinho Abrão (PTB/GO), que foi absolvido em julgamento polêmico em 1998. 
Contudo o consenso em torno daquela referência é vigoroso, extrapola o Legislativo e atravessa orientações políticas divergentes no cenário nacional, transformando-a, freqüentemente, em a problemática política legítima. Nesse sentido, observamos a qualificação dos políticos nas últimas eleições sendo orientada pelo seu comprometimento ou não com práticas corruptas, em uma estreita consonância com o amplo movimento pela ética na política que tem marcado a década de 90 em nosso país ${ }^{11}$. Desse modo, nem sempre de forma consciente, a luta por direitos políticos, no Brasil, tem priorizado a retidão pública e a penalização de sua quebra. Conseqüentemente, o debate acerca da dimensão fundamental da função política encontra-se imerso em e, por vezes, subordinado a virtudes de outra esfera: a burocracia. Não se trata aqui de desconsiderar o valor do exercício consciencioso e honesto da função pública, mas, sim, de refletir sobre o lugar específico desses valores na vida política, na qual a capacidade de tomar posição, de realizá-la e de responder por suas conseqüências compõe sua vocação maior.

Embora o "decoro parlamentar" seja previsto em instituições legislativas de outras democracias modernas, nestas adquire sentidos marcadamente distintos do que se verifica no Brasil. Na França, por exemplo, a expulsão de um parlamentar por decisão de outros parlamentares é considerada atentatória à vontade do eleitorado que o elegeu (Reale 1969). Esta interpretação não se verifica nos Estados Unidos, pois neste país o Congresso está autorizado pela Constituição a punir seus membros por "comportamento desregrado" (desordely behaviour). Todavia, apesar de esta concepção ter inspirado a instituição do decoro parlamentar no Brasil, ambos os processos legislativos guardam poucas semelhanças entre si.

Primeiro, o decorum nos Estados Unidos é uma noção mais restrita, vinculada em especial ao comportamento impróprio do parlamentar no uso da tribuna de uma das Casas Legislativas; os outros tipos de comportamento desregrado são denominados de "violação ética" , o que estaria de acordo com o predomínio dos valores individualistas e universalizantes do contexto norte-americano.

Segundo, o procedimento diante das violações éticas no Congresso norte-americano parece apresentar uma certa tendência para a construção de soluções negociadas, no sentido de evitar a perda do mandato parlamentar. Assim, nos Estados Unidos, dos mais de setenta deputados federais denunciados ao Comitê de Ética no período de 1789 a 1992, somente dois perderam o mandato e cinco renunciaram ao mesmo quando se encontravam em via de recomendação formal de expulsão. A maior 
parte dos deputados acusados de suborno foi punida com sanções do tipo reprovação e censura ou, ainda, multas pecuniárias ${ }^{12}$. Paga a dívida, liquida-se o ônus político. Em janeiro de 1997, por exemplo, vimos o deputado republicano Newt Gingrich, após ter sido condenado a pagar uma multa no valor de US\$300 mil por conduta fiscal aética, ser reeleito presidente da Câmara.

No Brasil, esse tipo de punição não é autorizado pelos regimentos internos e códigos de ética da Câmara (projeto em tramitação) e do Senado. Após a renúncia dos principais acusados de envolvimento no "escândalo do Orçamento" em 1994, foi aprovado um projeto que veda ao deputado ou senador que esteja sendo investigado ou processado o direito à renúncia. Desta perspectiva, a orientação política predominante no Congresso $\mathrm{N}$ acional parece ser oposta à tendência verificada no Legislativo norte-americano. Aqui, o movimento estaria se dando no sentido de buscar viabilizar a punição mais drástica (a cassação do mandato parlamentar) ou a absolvição do acusado. Um bom exemplo dessa tendência foi o desfecho dos processos oriundos da CPI do Orçamento, pois não houve gradação de punição: os parlamentares foram declarados inocentes ou perderam o mandato.

Essa orientação no estilo "tudo-ou-nada" seria condizente e reafirmaria os valores próprios ao universo da honra. Quando se trata de honra e dignidade, como no caso brasileiro, as soluções negociadas de qualquer natureza tornar-se-iam praticamente inviáveis. A penalização financeira, compensando procedimentos indecorosos, aqui perde a gramaticalidade. Assim, também, a responsabilização política em contextos de "decoro" dificilmente poderia ser esgotada em "meia-sanção". A sanção precisa ser definitiva. A cassação do parlamentar nesse contexto poderia ter como metáfora a instituição do "duelo" na honra medieval, ou seja, consistiria em uma solução por decreto de um tipo de morte: a morte política. Pois se o político ao ingressar no Congresso recebe por sua própria escolha um nome parlamentar ${ }^{13}$, adquirindo e confirmando por este procedimento de nominação que acompanha a investidura no cargo, uma personalidade política, a desonra dessa personalidade, nesse contexto, implicaria seu aniquilamento por meio da perda declarada do mandato parlamentar ${ }^{14}$.

A observação da especificidade do "decoro parlamentar" e seus correlatos em diferentes regimes democráticos contemporâneos, permite, para concluir, recolocar a necessária contextualização da honra na compreensão da vida política. Em realidades culturais distintas, a hierarquia de valores e os mecanismos políticos de sua atualização delineiam dife- 
rentes configurações para o universo da honra na política, o que vem reforçar a concepção weberiana do caráter essencialmente particularista da política e das tensões que este caráter engendra na interface com outras esferas de valor no mundo moderno, em especial com a ética.

Recebido em 13 de abril de 1998

Reapresentado em 30 de novembro de 1998

A provado em 14 de dezembro de 1998

Carla Costa Teixeira é professora do Departamento de Antropologia da Universidade de Brasília e pesquisadora do Núcleo de Antropologia da Política (NuAP). É autora do livro A Honra da Política (1998). 


\section{Notas}

* Este artigo se inspira em minha tese de doutorado A Honra da Política. “Decoro Parlamentar" e Perda de M andato no Congresso Brasileiro (1949-1994), onde desenvolvo uma leitura de $\mathrm{M}$ ax Weber à luz de material etnográfico referente a todos os casos de cassação de mandato de deputado federal ocorridos no Brasil até o ano de 1994 (Teixeira 1998).

1 Aqui se destacam a "teoria voluntarista da ação", de Talcott Parsons, e a "teoria da ação comunicativa", de J ürgen Habermas. Para uma análise abrangente da obra de Weber, cf. Schluchter (1989).

2 Os processos de cassação analisados foram os dos deputados Edmundo Barreto Pinto (PTB/RJ , 1949), J abes Rabelo (PTB/RO, 1991), Onaireves M oura (PSD/PR, 1993), N obel M oura (PSD/RO, 1993), Itsuo Takayama (PSD/M T, 1993), Ibsen Pinheiro (PMDB/RS, 1994) e Ricardo Fiúza (PFL/PE, 1994) (cf. Teixeira 1998).

3 Para estas reflexões consultar, em especial, o texto "Política como Vocação" (Weber 1998).

4 Cf., em especial, “Economía y Derecho” (Weber 1964) e os textos de Gunther Roth, "Religion and Revolutionary Beliefs" e "Charisma and the Counterculture" (Roth e Schluchter 1979).

5 Refiro-me aqui ao sentido de hierarquia nos termos do antropólogo Louis Dumont, para quem hierarquia implica uma totalidade (1) diferenciada em níveis e (2) composta por relações de englobamento e complementaridade entre as partes, que podem ser invertidas, havendo mudança de nível da realidade em questão (Dumont 1996).

6 Estamos próximos à discussão atual acerca do multiculturalismo - pauta de diferentes movimentos étnicos e feministas - abordada por Charles Taylor em Multiculturalism and “The Politics of Recognition” (1992).

7 Para uma reflexão mais sistemática das afinidades e distanciamentos teóricos entre Weber e Goethe, ver Goldman (1988).

8 Para reflexões acerca da honra em contextos onde a virilidade toma como modelo, não o soldado, o guerreiro ou o cavaleiro, mas valores ligados à família e à sexualidade masculina, sugiro consultar Peristiany (1971) e Pitt-Rivers (1977).

Ciudades)".

9 Cf., em especial, o texto “La Dominación No Legítima (Tipología de las 
10 Georg Simmel (1858-1918) fez parte dos círculos social e intelectual de Max Weber. Aqui me refiro, especificamente, ao texto de Simmel “A M etrópole e a Vida Mental" (Simmel 1987). Para informações gerais sobre as afinidades e distanciamentos entre o pensamento de ambos, cf. Weber (1974; 1986; 1993) e Simmel (1983). Para o desenvolvimento da noção de anonimato relativo, ver Velho (1987).

11 Um fato exemplar dessa tendência pode ser encontrado, em 1994, quando a Ordem dos A dvogados do Brasil (OAB), instituição de reconhecida atuação pelos direitos democráticos no Brasil, Iançou nacionalmente a "Campanha da cidadania pela valorização do voto". Cartazes e breves chamadas nos meios de comunicação foram divulgados com as seguintes palavras de ordem: TRAM BIQUE - não vote nele; GANÂNCIA — não vote nela; CORRUPÇÃO - não vote nela; FALCATRUA - não vote nela; CONCHAVO - não vote nele; IMPUNIDADE - não vote nela; MAM ATA - não vote nela.

12 Dados extraídos de Thompson (1995). Os dois casos de perda de mandato foram: (1) denúncia de "misuse of office/obstruction of legislative process", em 1967; (2) denúncia de “bribery/influence peddling”, em 1980. O autor não oferece, porém, maiores informações sobre os processos.

13 Dentre os deputados investigados em minha tese, apenas Edmundo Barreto Pinto manteve o nome de batismo como nome parlamentar. Os demais deputados cunharam, desde as primeiras campanhas eleitorais, um outro nome, em geral, por abreviação do nome de batismo: J abes (Pinto) Rabelo; Onaireves (Nilo Rolim de) Moura; (Antonio) Nobel (Aires) Moura; Ibsen (Valls) Pinheiro; Ricardo (Ferreira) Fiúza. O deputado Itsuo Takayma, por ter assumido o mandato por suplência, não consta do índice onomástico do Repertório Biográfico (1991-1995) produzido pela Câmara; não tive, portanto, condições de averiguar a correspondência entre seu nome de batismo e o nome parlamentar.

${ }^{14}$ Aqui vale lembrar expressões como "corredor da morte", utilizada para a CPI do Orçamento, e também as manchetes acerca da cassação de Ibsen Pinheiro: "Ibsen foi degolado" e "Ibsen moído". 


\section{Referências bibliográficas}

DUM ONT, Louis. 1996. Homo Hierarchicus. O Sistema das Castas e suas I mplicações. São Paulo: Editora da Universidade de São Paulo.

GOLDM AN, Harvey. 1988. Max Weber and Thomas Mann. Calling and Shaping of the Self. Berkeley: University of California Press.

PERISTIANY, J ohn G. 1971. Honra e Vergonha: Valores da Sociedade M editerrânica. Lisboa: Fundação Calouste Gulbenkian.

PITT-RIVERS, J ulian. 1977. The Fate of Shechem or the Politics of Sex. Cambridge: Cambridge University Press.

REALE, Miguel. 1969. “Decoro Parlamentar e Cassação de M andato Eletivo". Revista de Direito Público, 2 (10).

ROTH, Gunther E SCHLUCHTER, Wolfgang. 1979. Max Weber's Vision of History. Ethics and M ethods. Berkeley: University of California Press.

SCHLUCHTER, Wolfgang. 1989. Rationalism, Religion, and Domination. A Weberian Perspective. Berkeley: University of California Press.

.1996. Paradoxes of Modernity. Culture and Conduct in the Theory of Modernity. Stanford: Stanford University Press.

SIMMEL, Georg. 1983. Simmel (organizado por Evaristo de M oraes Filho). São Paulo: Ática. . 1987. “A M etrópole e a Vida Mental". In: O. Velho (org.), O Fenômeno Urbano. Rio de J aneiro: Editora Guanabara. pp. 13-28.

TAYLOR, Charles. 1992. Multiculturalism and "The Politics of Recognition". Princeton: Princeton University Press.
TEIXEIRA, Carla. 1998. A Honra da Política. "Decoro Parlamentar" e Perda de $\mathrm{M}$ andato no Congresso Brasileiro (1949-1994). Rio de J aneiro: Relume-Dumará.

THOMPSON, Dennis. 1995. Ethics in Congress. From Individual to Institutional Corruption. Washington, D.C.: The Brookings Institution.

VELHO, Gilberto.1987. Individualismo e Cultura. Rio de J aneiro: J orge Zahar Editor.

WEBER, Max. 1964. Economía y Sociedad I. M éxico/Buenos Aires: Fondo de Cultura Económica. . 1974. Ensaios de Sociologia (editado por Hans Gerth e C. Wright Mills). Rio de J aneiro: Zahar Editores. . 1986. Max Weber (organizado por Gabriel Cohn). São Paulo: Ática. . 1993. Metodologia das Ciências Sociais (Parte 1). São Paulo/Campinas: Cortez/Editora da Unicamp. . 1995. Metodologia das Ciências Sociais (Parte 2). São Paulo/Campinas: Cortez/Editora da Unicamp. . 1998. Ciência e Política. Duas Vocações. São Paulo: Editora Cultrix. 


\section{Resumo}

O objetivo deste artigo é explorar o entendimento weberiano da esfera política, elegendo como ângulo de inserção a teoria de valor subjacente à obra de Max Weber e, como inspiração, o material etnográfico oriundo de minhas pesquisas acerca das concepções de decoro parlamentar no Congresso N acional no período entre 1949 e 1994 . Dessa perspectiva, o texto discute o conceito de vocação dos políticos e da política no mundo moderno, buscando compreender os critérios e valores decisivos da vida política em sua autonomia vis-à-vis as demais esferas de valor. Ao longo desse empreendimento, analiso a noção de honra e de ética da responsabilidade como categorias centrais à existência do político de vocação e a própria especificidade do domínio político, tomando como guia, para tal releitura dos textos weberianos, os trabalhos de Wolfgang Schluchter.

\section{Abstract}

This article aims to explore the Weberian understanding of the political sphere, taking as its angle of approach the theory of value underlying Max Weber's work, and as its inspiration, the ethnographic material originating from my own research into conceptions of parliamentary decorum in the Brazilian National Congress during the period between 1949 and 1994. Working from this perspective, the paper discusses the concept of vocation adhered to by politicians and politics in the modern world, and seeks to comprehend the key criteria and values of political life in its autonomy vis-à-vis other valueladen spheres. In the course of this undertaking, I analyze the notions of honour and ethical responsibility as categories central to the existence of professional politicians and to the specific nature of the political domain, taking the works of Wolfgang Schluchter as a guide to the accompanying re-reading of Weber. 